\title{
AN ASSOCIATION OF CENTRAL POST-STROKE PAIN AND THALAMIC HAND
}

\author{
C.M. DE CASTRO-COSTA* - O.C. DO VALE**-J.I. SIQUEIRA NETO***
}

SUMMARY - Thalamic hand is one of the clinical expressions of the painful thalamic syndrome. This paper relates on a case of a patient with a syndrome of central post-stroke and suprathalamic pain who also presents a thalamic hand. The authors emphasize the notion that in the syndrome of central post-stroke pain a direct or indirect (infra or supra)thalamic lesion seems to be an essential element for the genesis of central pain.

KEY WORDS: pain, post-stroke pain, suprathalamic pain, thalamic hand.

Associação de dor central pós-icto o mão talâmica.

RESUMO - A mão talâmica é um dos sinais clínicos na síndrome talâmica. Neste estudo é relatado o caso de uma paciente com síndrome de dor central (supratalamica) pos-ictal que apresenta também mão talâmica. Os autores enfatizam a noção de que na síndrome de dor central pos-ictal, uma lesão talâmica direta ou indireta (infra ou supratalâmica) é elemento fundamental para a gênese da dor central.

PALAVRAS CHAVE: dor, dor pós-icto, dor supratalâmica, mão talâmica.

Central neurogenic pain is a challenging clinical phenomenon from the physiopathological and therapeutical point of view. One of the well-known conditions of central pain is the syndrome of thalamic pain mostly of vascular origin 7,11. Firstly described by Dejerine and Roussy in 1906, this syndrome is characterized by a slight hemiparesis, hemidisturbance of superficial and deep sensibility, hemiataxia with a dystonic (thalamic) hand, hemiastereognosia, choreothetoid movements and a condition of intolerable pain in the affected side which is disclosed by innocuous stimuli 4,5,9,11. More recently an emphasis is placed on the syndromes of central post-stroke pain with original lesions placed in infra or suprathalamic sites and with possibly different clinical expressions and mechanisms 7.

This paper aims at reporting on a case of association of central post-stroke pain and thalamic hand, and its physiopathological meaning.

\section{CASE REPORT}

ISS, a female 54 years old patient, single and beggar. Her clinical history began 5 years ago when she had fallen from a hammock, with an acute development of a slight weakness in right side of the body. Subsequently she presented abnormal movements in the right arm and leg and complained of pain in the right body including the face. As

Service of Neurology, Hospital Universitário Walter Cantídio, Universidade Federal do Ceará (UFCe), and Laboratory of Experimental Neurology, Department of Physiology and Pharmacology, UFCe; *Adjunct Professor, M.D., M.S., Ph.D.; ** Adjunct Professor, M.D. ; *** Resident, M.D.

Dr. C. M. de Castro Costa - Departamento de Fisiologia e Farmacologia, Centro de Ciências da Saúde, UFCe - Caixa Postal 657 - 604:30 Fortaleza CE - Brasil. 
antecedents, she had a history of convulsions, alcoholism and pulmonary tuberculosis in the past. The phsysical examination revealed a diminished vision in both eyes. The neurological examination showed: discrete temporospatial disorientation; preserved force on the members with osteotendinous reflexes more vivid in the right arm and leg; slight hypertonia in the right side; dystonia of the right hand characterized by flexion of the third and fourth fingers and extension of the second and fifth fingers in a fixed posture (thalamo-pallidal hand); the coordination was normal but she had a paretic walk; hyperesthesia of the side of the body with hyperpathic pain disclosed by discriminatory and blunt tactile stimuli, pressure and chiefly by cold and pinprick. Exams revealed: normal blood and ions study; normal urine; normal cranial radiogram; radiological residua of ancient tuberculosis in the upper lung; normial abdominal ecography. A cranial computerized tomography showed an extensive lesion in the left parieto-occipital transition with density similar to that of cerebrospinial fluid; this lesion resembled a cyst with possible communication with the posterior horn of the lateral ventricle; there was no abnormal captation when a contrast was injected. The analysis of the evoked somatosensory potentials showed a complete block of the proprioceptive conduction between the left medial lemniscus and the parieto-occipital cortex. A treatment with carbamazepine $(600 \mathrm{mg} / \mathrm{day})$ was introduced with moderate relieve of pain.

\section{COMMENTS}

The presence of a pain syndrome in the right side of this patient and the evidence of a suprathalamic lesion as seen by CT findings arise the notion that the syndrome of thalamic pain is part of a larger set of symptoms derived from infra or suprathalamic lesions. Our patient presented some of the characteristics of the thalamic pain syndrome, i. e, the hyperpathic symptomatology, the dystonic hand, but with a diagnosis of a syndrome of central post-stroke pain (CPSP). In CPSP the somatic sensibility is not severely affected excepting for temperature and pain modalities 1,8,10. It affects mostly males, the left side of the body and occurs in a mean age of 62 years old. The cardinal symptom is hypersensitivity (hyperpathia) to mechanical or thermal stimuli $3,6,8,10$ and the onset of the symptoms may range from three months to three years after the stroke, which is the most frequent etiology 3 .

The mechanisms of this pain condition are not yet well known. Hypotheses include concepts such as desintegration in the somatosensory systems, removal of inhibitory influence via the lemniscal pathways or the presence of hyperexcitable and/or spontaneously active zone due to central deafferentation. It seems that the crucial factor for the development of CPSP is a lesion of the spinothalamic pathway in any of its levels $\mathbf{2 , 3}$. The central post-stroke pain may be relieved by carbamazepine or amytriptiline in low doses 7.

In our case, the patient presented a thalamic syndrome without an evident CT thalamic lesion. And among the thalamic symptoms, the dystonic hand was an important sign besides hyperpathia. The dystonic or thalamic hand is expression of an ataxia and it may present with abnormal small movements (thalamo-striatal hand) or with a fixed position (thalamo-pallidal hand) ${ }^{4,9}$. It may be consequent to a neostriate degeneration or to a degeneration of the fibers that connect with the striatum.

Because the existence of a suprathalamic lesion (parieto-occipital) in our case we may make the following speculations on CPSP: (1) The so-called «thalamic syndrome» may represent $\dot{z}$ wider range of lesions and symptoms so that the denomination of syndromes of centiral post-stroke pain may be more appropriate. (2) The thalamus is somehow implicated in the genesis of CPSP even when the lesion is outside it; this may possibly occur by a retrograde or anterograde degeneration of fibers or neurons from the impaired area which is connected with the thalamus, this way disrupting its gating function for pain control. (3) The presence of a dystonic hand in our patient is a sign of thalamic involvement and this reinforces our hypothesis of this essential and fundamental participation of the thalamus for the origin of central pain. 


\section{REFERENCES}

1. Ajuraguerra J. La Douleur dans les Affections du Sistème Nerveux Central. Paris: Doin, 1937.

2. Beric A, Dimitrijevic MA, Lindblom $U$. Central dysesthesia syndrome in spinal cord injury patients, Pain 1988, 34:109-116.

3. Boivie J, Leijon G, Johansson I. Central post-stroke pain: a study of the mechanisms through analyses of the sensory abnormalities. Pain 1989, 37:173-185.

4. Contamin F, Sabouraud O. In Eléments de Neurologie: Sémiologie Analitique et Syndromes. Ed 2. Paris: Flamarion, 1968, p 169-171.

5. Déjérine J, Roussy G. Le syndrome thalamique. Rev Neurol (Paris) 1906, $12: 54$.

6. Head H, Holmes G. Sensory disturbances from cerebral lesions. Brain 1911, 34:102.

7. Leijon G, Boivie J, Johansson I. Central post-stroke pain: neurological symptoms and pain characteristics. Pain 1989, 36:13-25.

8. Pagni CA. Central pain due to spinal cord and brain stem damage. In Wall PD Melzack R (eds) Textbook of Pain. London: Churchill Livingstone 1984, p 481-495.

9. Pedro-Pons A, Valenti PF, Ley A, Esteve S.M, Vasquez RS, Burbano RS, Colomer ET Puiggrós AC, Sambó JM, Badó JV. In Enfermedades del Sistema Nervioso, Neurosis y Medicina Psicosomatica. Enfermedades Mentales Tomo IV. Barcelona: Salvat 1965. p 113-115.

10. Riddoch $G$. The clinical features of central pain. Lancet 1938, 234:1093-1098, 1150-1156, 1205-1209.

11. Rosa DE, Gamarra FH, Vieira JBA, Machado REM. Sindrome de Déjérine-Roussy. Arq Neuro-Psiquiat (São Paulo) 1984, 42:175-178. 